\title{
Works Councils and Firm Productivity in France
}

\author{
David Fairris • Philippe Askenazy
}

Published online: 22 May 2010

(C) The Author(s) 2010. This article is published with open access at Springerlink.com

\begin{abstract}
This paper utilizes establishment-level data to explore the impact of works councils on firm productivity in France. A variety of empirical techniques is employed, including fixed effects and regression discontinuity designs, to identify this impact. We estimate the works council effect on productivity in union and nonunion settings, and investigate the extent to which alternative forms of worker voice and information sharing might substitute for the works council's impact in production. We find no evidence of a positive impact of works councils on firm productivity in any of our results, and some limited evidence of a negative effect in some of the findings. There is no indication that estimated impacts on productivity vary with union status. However, a notable finding is that worker voice and information-sharing human resource practices are prevalent in French firms regardless of works council status, and are found to have positive and statistically significant effects on firm productivity.
\end{abstract}

Keywords Works council · Productivity· Worker voice

JEL Classification $\mathrm{J} 53 \cdot \mathrm{J} 58 \cdot \mathrm{J} 51$

\section{Introduction}

Works councils are an enduring feature of industrial relations in continental Europe, encouraging labor-management cooperation through the joint sharing of information, consultation, and, in some cases, co-determination regarding important firm decisions such as workplace health and safety and overtime work. With the

D. Fairris $(\bowtie)$

Department of Economics, University of California, Riverside, CA 92521, USA

e-mail: david.fairris@ucr.edu

P. Askenazy

Paris School of Economics-CNRS, 48 boulevard Jourdan, 75014 Paris, France 
European Directive on Information and Consultation, which mandated consultative mechanisms throughout EU workplaces beginning in 2008, the impact of works councils are of growing interest in European countries. However, empirical evidence on the impact of works councils on industrial relations and firm performance is largely limited to the case of Germany. ${ }^{1}$ In this paper we present the first empirical evidence of which we are aware on the impact of works councils on firm productivity in France.

The French case is an interesting contrast to the German one. French works councils are much less aligned with trade unions, they possess no statutory codetermination rights, and they are mandated for firms above fifty workers as opposed to firms above five. Exploring the productivity impact of works councils in union and nonunion settings is thus easier in the French than in the German case because the two forms of worker representation are less co-mingled in the former. The higher worker threshold before works councils are mandated by law affords our analysis a healthier proportion of firms without works councils and thereby allows a meaningful opportunity to employ a regression discontinuity research design in exploring the works council impact on productivity.

In addition, and in contrast to much of the German analyses, our data contain a good measure of the capital stock of firms, which is crucial to the estimation of production functions. The French data we employ are relatively short of establishment-level control variables, but our fixed effects estimation strategy serves to partially overcome this drawback. We possess good measures of both union status and establishment workplace practices that allow for an exploration of the extent to which informal mechanisms for worker voice and information-sharing may substitute for works councils in productivity outcomes in France.

The results of our analysis are mixed. We find no evidence of a positive impact of French works councils on firm productivity, and in fact some limited results suggesting a negative impact on productivity. Union status appears to have no influence whatsoever on the estimated productivity impact of works councils. However, human resource practices associated with worker voice and information sharing - features commonly associated with works councils - are widespread in French firms and, according to our findings, have a positive and statistically significant impact on firm productivity.

\section{Theory and Empirical Evidence on Works Councils and Productivity}

Theory suggests that works councils may enhance firm productivity in a variety of ways: ${ }^{2}$ They may provide a forum in which workers share valuable knowledge of production with management or in which discussions between labor and management per se yield useful ideas for productivity improvements (Freeman and Lazear 1995). Firms with works councils may also be more productive because they are

\footnotetext{
${ }^{1}$ The Kleiner and Lee (1997) study using data on South Korea, which reveals a positive and statistically significant impact of works council on productivity in that country, is an important exception.

2 A new book by Addison (2010) offers an exhaustive treatment of both the theory behind works council impacts in production and the empirical evidence to date on these impacts in the German case.
} 
more successful in overcoming the negative consequences - retaliatory worker shirking or suboptimal worker investment in firm-specific training-typically associated with the employer "hold-up" problem. In long-term relationships with incomplete contracting, firms have an incentive to reduce wages and benefits in an attempt to appropriate worker quasi-rents by falsely claiming economic distress in the firm. Works councils may act as credible mechanisms for verifying the economic status of the firm to the workforce, and thereby prevent this opportunistic behavior by employers and the negative outcomes for productivity that may flow from it (see Addison 2010).

Theory suggests that works councils may also have a negative effect on firm productivity. To the extent knowledge of and involvement in the production process leads to worker empowerment, works councils may become appropriative agencies in production in much the same way as firms with sole managerial prerogative are viewed in the hold-up problem described above. This is acknowledged even by those who are inclined towards a sympathetic view of the productivity-enhancing effects of works councils in production (see, for example, Freeman and Lazear 1995).

It is also possible that works councils reduce firm productivity even as they enhance the joint surplus from production, once one accepts the position that the joint surplus includes workplace features such as worker health and safety or a moderate work pace which workers value and yet which may compromise productivity. If the combination of wages and working conditions as determined by market forces is allocatively suboptimal, works council voice may lead to an alteration of the overall compensation package - a lowering of wages, for example, in exchange for improvements in working conditions - in such a way that lowers firm productivity at the same time that it enhances the joint surplus from production. ${ }^{3}$ In this view, productivity, which is a barometer for the wages of workers and the profits of firms, is not an accurate indicator of the joint surplus from production because workers also care about working conditions, improvement in which may require that productivity be compromised (Fairris 2002).

When considering the impact of works councils in production, it must be noted that this particular form of worker voice may be neither necessary nor sufficient for the various enhancements in firm productivity with which it is sometimes associated. Works councils may be unnecessary if similar productivity enhancements can be generated via informal worker voice mechanisms and information-sharing arrangements outside of formal works council structures.

Informal mechanisms for worker voice and information sharing have grown rapidly across the globe in recent decades following evidence that Japanese production methods which possess such arrangements-e.g., quality circles and teams in production - generate high levels of firm productivity. France was among the many countries to experiment with informal voice and information sharing arrangements beginning in the 1970s and 1980s (Jenkins 2000). The spread of such arrangements may have reduced the importance of works councils as generators of mutually advantageous changes in production that lead to increased productivity. Information sharing with employees, even in the absence of a worker-based collective entity to verify this information, may reduce the hold-up problem referred

\footnotetext{
${ }^{3}$ Theory tells us, for example, that collectively-experienced working conditions outcomes will reflect the preferences of the marginal rather than the median worker when determined by market forces.
} 
to above. Allowing workers some decision making or voice in production, even though it operates outside the formal and collectivist confines of the works council, may also lead to productivity enhancements.

In addition to being unnecessary, works councils may be insufficient to generate the productivity gains with which they are sometimes associated if they lack the power to ensure that workers share in the rewards from adjustments in production that yield a productivity increase. Workers are unlikely to make suggestions that increase the joint surplus if their implementation would alter the distribution of rewards from production in management's favor. Thus, there may be a natural limit to the effectiveness of works councils unless workers possess some distributive power in production in addition to pure collaboration and consultation rights.

Works councils in France are not very powerful. Compared to their German counterparts, French works councils lack state-sanctioned co-determination rights that grant labor virtual parity with management in decision-making over a range of production decisions that affect workers. However, co-determination rights are not the only way to endow works councils with the power to ensure that workers share in the rewards from efficiency-enhancing changes in production. Independent unions may serve as an equally effective force for labor in this regard. ${ }^{4}$ Works councils and unions may therefore be complementary forces in the enhancement of firm productivity.

The empirical literature on the impact of works councils on firm productivity is largely restricted to the German case. Addison (2010) offers a comprehensive review of the existing literature. The early literature, which was plagued by small sample sizes and industry or regional specificity, was generally not supportive of a positive impact of works councils on firm productivity. Addison divides the more modern literature, which makes use of larger-scale data sets, into two phases. The first offers a significantly more positive view of the works council effect on productivity, in some part because of the introduction of new variables - such as collective bargaining, employee involvement, and establishment size-into the analysis. An illustrative paper is Addison et al. (2001), who find a positive productivity effect of works councils except in smaller size (21-100 worker) plants.

The third phase of research on the productivity impact of works councils in Germany is characterized by the use of panel data, allowing for fixed effects estimation, and the use of more sophisticated econometrics techniques, such as propensity score matching and selection modeling. In almost every case, the empirical findings are much more mixed than in the second phase of research, with some studies finding a positive and statistically significant impact of works councils on productivity but a majority indicating no statistically significant effect. Addison et al. (2006) offer an interesting contrast between the second and third phases of this research. After establishing a strongly positive and statistically significant impact of works councils on productivity in their pooled panel data (except, once again, for plants with 21-100 employees), the authors' fixed effects estimates using these same data contain little evidence of a positive works council effect on productivity.

\footnotetext{
${ }^{4}$ This point was made by Paul Douglas (1921), who argued that the works council-like shop committees of the 1920s in the US were complements to and not, as commonly viewed by labor and management at the time, substitutes for independent trades unions in increasing the overall benefits to labor and capital in production. In Douglas' view shop committees cooperated with management to generate productive efficiency and unions ensured that workers shared in the rewards that followed.
} 
There is a small number of studies in the German case with evidence on whether alternative forms of worker voice and information sharing may act as substitutes for (or perhaps even complements to) works councils in production. One group of studies merely focuses on the extent to which they coexist. Addison et al. (1997) find that the incidence of teamwork is much lower in works council settingssuggestive of a substitute relation-whereas Gerlach and Jirjahn (2001) find that group incentive schemes are more prevalent in firms with works councilssuggestive of a complementary relation between the two.

There are only two studies that explore specifically the joint impact of works councils and alternative voice forms on productivity: Zwick (2004), who finds that works councils bolster the impact of employee involvement schemes on productivity, and Hubler and Jirjahn (2002), who find mixed results, one suggesting a positive impact on productivity where works councils coexist with teams in production and another suggesting a negative impact where they coexist with a reduction in hierarchical decision making in production. Interestingly, Zwick (2004) finds a positive impact of employee involvement schemes solely in settings where they coexist with works councils.

Only a handful of papers in the German literature explore specifically the potential complimentary relation between works councils and unions, but most find a positive works council impact on productivity in establishments (and sometimes exclusively in such establishments) where there exist collective bargaining agreements (Hubler and Jirjahn 2003; Wagner 2008). This is consistent with the Freeman and Lazear and Douglas view of industrial relations systems, where worker voice and worker empowerment join forces to generate positive effects for both workers and firms.

\section{Works Councils and Unions in France}

French law grants workers rights of participation in the affairs of firms according to the size of the establishment or firm. There are two main forms of statutory nonunion representation in France.

The first is the workforce delegate (délégué du personnel or $D P$ ). A workforce delegate is required by law in all firms or establishments with ten or more employees, regardless of union status. A workforce delegate is elected for a 2-year term by the employees, and the delegate's role consists in presenting individual and collective grievances to management. The delegate is also responsible for conveying to government inspectors complaints in connection with the possible violation of labor regulations. This is the most widespread form of non-union employee representation in France, but the powers and responsibilities of workforce delegates are limited in comparison with those of a second form of non-union worker representation - namely, works councils.

Works councils (Comités d'Entreprise) have been a compulsory form of worker representation since 1945 in French firms with over 50 employees. The works council in France is a collective body composed of worker representatives who are elected by the workforce. The minimum number of elected representatives is fixed by the government according to the size of the establishment (e.g. three 
representatives in establishments with 50 to 74 workers). Prior to 2005 , works council representatives were elected every 2 years; currently, they stand for 4 year terms. Participation in the election of works council representatives is consistently above $60 \%$, making them bodies that are highly representative of the workforce as a whole. The head of the firm or establishment chairs the works council.

While works councils are mandated by law in establishments of over 50 workers, if too few candidates emerge for representative positions, no works council may exist. Also, if works council representatives leave or retire and no replacements emerge, the works council may be disbanded. Occasionally employers may put pressure on potential candidates not to run for works council positions in hopes of thereby avoiding works councils in the firm. However, this behaviour is uncommon and predominately found in service sector firms. Works councils are also observed in establishments below the 50-worker threshold, when for example an employer organizes works council elections in order to improve the dialogue between labor and management inside the firm.

The works council has consultative powers in regard to all significant employer initiatives concerning the organization and management of the firm, including for example collective layoffs and technological changes. The employer has to inform the works council before initiating any such changes and the work council representatives may poll the workforce for advice on the changes. The employer also has to provide the works council with information on the financial situation of the firm. While the works council possesses little formal bargaining power or rights of co-determination in such matters, in practice numerous agreements, both formal and informal, are concluded between the head of an enterprise and the works council, and the labor courts may accord these agreements a legal force. The works council is typically granted full control over company welfare and cultural facilities.

Whereas works councils are the main body fostering collective discussions between labor and management, it is unions - and their representatives in the form of the Union delegates (Délégués syndicaux or DS) - that possess the bargaining power for workers. Since the Auroux' laws in 1982, unions and representative bodies of workers such as works councils may coexist in French firms, under the principle that unions bargain with the employer while works councils foster a sharing of information that leads to mutually beneficial outcomes.

Union delegates are generally not elected. Every representative union which has members in a firm with more than 50 employees is entitled to a trade union delegate. In firms with fewer than 50 employees, an elected workforce delegate may be appointed to act simultaneously as a union delegate. Union delegates represent their trade union in bargaining with the head of the firm, but have the task of protecting the interests both of the union members and of the workforce as a whole. The employer has to bargain each year with union delegates on wages, hours of work, and working conditions. The agreements have legal force and they apply to all workers even if they are not union members.

In unionized establishments, union members may assume the roles of workforce delegates, works council representatives, and union delegates. In firms with union delegates, these delegates participate in the works council, but they do not vote if they are not elected as works council representatives. In this way, concerns of workers raised through works council discussions may become bargaining demands 
in union negotiations. As our data indicate, worker representation through works councils is more widespread in France than representation through unions.

\section{Data}

This paper relies on two datasets-REPONSE and Diane-which are merged to conduct the analysis of the works council impact on firm productivity. REPONSE (RElations PrOfessionnelles et NégociationS d'Entreprise) is a survey of establishments conducted jointly by the French Ministry of Labor and the National Institute of Statistics and Economic Studies (INSEE). Taking roughly 1 hour on average to complete, senior managers answer survey questions in face-to-face interviews with survey enumerators. REPONSE is gathered primarily to provide consistent information to the government on labor relations - including workforce representation, conflicts, and collective bargaining - and on the internal organization and recent technological changes in production. The REPONSE data has been used extensively in economics research (see, for example, Caroli and Van Reenen 2001; Askenazy et al. 2006).

We utilize the 1999 and 2005 REPONSE surveys for the analysis in this paper. These are separate cross-sectional establishment surveys, including more than 2,500 establishments during each administration with a response rate averaging a respectable $60 \%$ over both administrations. The sample is a random selection from the exhaustive INSEE establishment records, excluding agriculture and public-sector enterprises, and is stratified by establishment size. The years 1999 to 2005 are a particularly relevant period for our study in that this period witnessed significant changes in both works council status and union coverage corresponding with implementation of the 35-hour workweek.

We utilize the REPONSE surveys to record works council status, union status, and a variety of other establishment-level measures including worker voice and information sharing features. The "works council" and "union" variables account for whether or not there is a works council or union bargaining agent present in the firm. The works council variable simply asks if there is a works council present, whereas the union variable asks if there is a "union delegate" in the firm. As noted above, union delegates are the legal representatives of unions in French firms; employers are compelled by labor law to bargain with union delegates at least once a year over wages, hours of work, and working conditions.

"Employee decision making" is a measure of worker voice in the firm, and specifically the autonomy workers possess in production in resolving difficulties without having to consult or receive approval from management. "Information to employees" captures the extent to which firms inform employees regarding such matters as technological and organizational changes, firm strategy, economic performance, and even the environmental impact of the firm. The REPONSE data possess a major limitation in comparison with some of the German data in that they contain fewer establishment-level control variables for use in the regression analysis. We estimate a fixed effects model of firm productivity to address this limitation, but, as we shall see, the fixed effects estimation itself has certain limitations.

The second dataset-Diane (diane.bvdep.com) — is at the firm, as opposed to establishment, level and comes from a private source. Diane compiles public balance 
sheets that firms must provide to the commercial courts (i.e., greffes des tribunaux de commerce). The database is not entirely exhaustive because firms may choose to keep secret their corporate information and incur a fine as a consequence. Diane contains various statistics on firm balances including value-added and sales, as well as workforce size. ${ }^{5}$ It also gives the complete yearly fiscal sheets (i.e., liasse fiscale). The advantage of these fiscal sheets is that we can compute estimates of the capital stock for individual firms. There exists a variety of methods to derive such estimates from these data, but the literature generally prefers a measure of the gross capital stock at current cost (OECD 2001). This estimate is derived using the following formula:

Gross capital stock at current cost $=$ Gross capital stock at historical cost

$$
\begin{aligned}
& \times(1+\text { average inflation rate of investment } \\
& \times \text { average age of capital stock }) .
\end{aligned}
$$

The inflation rate of investment is given by INSEE (about $2 \%$ for studied firms), and the average age of capital is assessed at 27 years for buildings and 9 years for equipment. The balance sheets provide directly the gross capital stock at historical cost - a less sophisticated measure which is nonetheless strongly correlated with the value at current cost that we use here, even after correcting for the size effect. Although Diane provides the annual average size of the firm workforce, it contains no information on actual hours worked; thus, in this analysis labor input is measured in terms of the number of workers as opposed to the number of worker hours.

These two data sets were merged based on firm identifiers. Because we lack works council information for every establishment in multi-establishment firms, and productivity information at the individual establishment level, our analysis in this paper is restricted to single-establishment firms. This is obviously a nonrepresentative sample of firms in France, ${ }^{6}$ but it has the virtue of directly relating works council status of an individual productive unit to the productivity level of that unit. In multi-establishment firms, works councils may exist at the firm level as well as at each establishment level. However, the existence of a firm-level works council is a questionable measure to use in estimating the works council impact on productivity, which is best estimated with information on works council status and productivity at the level of the productive unit-i.e., the establishment.

After merging the two data sets and omitting those with missing observations on key variables, there are a total of 1008 single establishment firms for analysis over the two periods. Because we possess firm identifiers, it is possible to create a panel data set composed of those firms that appear in both survey years; there are 109 such firms, composing 218 of the 1008 observations in the combined cross-sectional data. We refer to the larger data set as the "pooled" data and to the smaller data set as the "panel" data. Table 1 gives the variable definitions and Table 2, the descriptive

\footnotetext{
${ }_{5}$ All balance variables are in constant euros.

${ }^{6}$ Even compared to all single establishment firms in France, these data are slightly unrepresentative in that they are restricted to firms with twenty or more workers. Compared to the larger INSEE establishment file for single establishment firms, we find that sectors with smaller size firms (e.g., retail trade, finance and real estate, and personal services) are slightly underrepresented in our data, whereas sectors with larger establishments (e.g., consumption goods, equipment goods, and intermediate goods) are overrepresented.
} 
Table 1 Variable definitions

\begin{tabular}{ll}
\hline Variable & Definition \\
\hline Value Added & Valued Added (in millions of constant Euros) \\
Capital & Estimated Capital Stock (in thousands of constant Euros) \\
Workforce & Number of Employees \\
Workforce50 & 1 If Workforce is Greater Than or Equal to 50; 0 Otherwise \\
Works Council & 1 If there is a Works Council Present in the Firm; 0 Otherwise \\
Union & 1 If there is a Union Delegate Present in the Firm; 0 Otherwise \\
Employee Decision Making & 1 If Firm Encourages Employee Decision-Making in Case of a \\
& Difficulty or Incident in Production; 0 If Employees Must First \\
& Consult with Management \\
Information to Employees & 1 If Firm Regularly Disseminates Information About the Firm's \\
& Performance to Workers; 0 If Sometimes/Never \\
Time & 1 If 2008; 0 Otherwise \\
Industry & 11 Industry Categorical Variables
\end{tabular}

statistics. Table 2 reveals that, for the pooled data, the density of unions, works councils, and firms with employee decision making declined over the period 1998 to 2004, whereas information sharing arrangements witnessed an increase. These changes are generally tempered somewhat in the panel data, and in the case of works councils the direction of change is reversed-works council density rises in this sample.

\section{Empirical Methodology}

Our strategy is to estimate total factor productivity regressions, where the dependent variable is the residual from a simple log-in-log production function of the following form:

$$
V A_{\mathrm{it}}=\varphi_{0}+\varphi_{1} \text { workforce }_{\mathrm{it}}+\varphi_{2} \text { capital }_{\mathrm{it}}+e_{\mathrm{it}},
$$

where $V A_{\text {it }}$ is value added in production.

We invoke a variety of identification strategies to estimate the causal impact of works councils on total factor productivity, each of which is mindful of the fact that while the pooled data are formed from two independent surveys of establishments, they nonetheless contain a subset of firms with two observations at separate points in time. ${ }^{7}$ The basic specification is as follows:

$$
\text { TFP }_{\text {it }}=\alpha_{0}+\alpha_{1} w c_{\text {it }}+\alpha_{2} \text { union }_{\text {it }}+\alpha_{3} \text { voice }_{\text {it }}+\alpha_{4} \text { info }_{\text {it }}+\alpha_{5} \text { time }+\alpha_{6} I_{\mathrm{it}}+\varepsilon_{\mathrm{it}},
$$

where TFP is the residual from estimation of Eq. 1 above, voice is the employee decision making variable, info is the information to employees variable, $I$ is a vector of industry categorical variables, wc represents the works council variable, and the

\footnotetext{
${ }^{7}$ A Chow test failed to reject the null hypothesis of no structural differences across separate 1998 and 2004 productivity regressions, suggesting that it is acceptable to pool the data and estimate a single productivity regression with a time dummy to capture the inter-temporal nature of the data.
} 
Table 2 Descriptive statistics

\begin{tabular}{|c|c|c|c|c|c|c|c|c|c|}
\hline \multirow[t]{3}{*}{ Variables } & \multicolumn{6}{|c|}{ Cross sections and pooled } & \multirow{2}{*}{\multicolumn{3}{|c|}{$\frac{\text { Panel }}{\text { All establishments }}$}} \\
\hline & \multicolumn{3}{|c|}{ All establishments } & \multicolumn{3}{|c|}{$\begin{array}{l}\text { Establishments with } \\
\text { workforce } 30-70\end{array}$} & & & \\
\hline & 1998 & 2004 & $\begin{array}{l}1998 \\
2004\end{array}$ & 1998 & 2004 & $\begin{array}{l}1998 \\
2004\end{array}$ & 1998 & 2004 & $\begin{array}{l}1998 \\
2004\end{array}$ \\
\hline Valued Added & $\begin{array}{l}16761 \\
(4538)\end{array}$ & $\begin{array}{l}23693 \\
(3473)\end{array}$ & $\begin{array}{l}20681 \\
(2783)\end{array}$ & $\begin{array}{l}2001 \\
(118)\end{array}$ & $\begin{array}{l}2344 \\
(126)\end{array}$ & $\begin{array}{l}2194 \\
(88)\end{array}$ & $\begin{array}{l}14220 \\
(2563)\end{array}$ & $\begin{array}{l}16678 \\
(2643)\end{array}$ & $\begin{array}{l}15449 \\
(1839)\end{array}$ \\
\hline Capital & $\begin{array}{l}24665 \\
(4289)\end{array}$ & $\begin{array}{l}45350 \\
(10334)\end{array}$ & $\begin{array}{l}36362 \\
(6140)\end{array}$ & $\begin{array}{l}3267 \\
(1203)\end{array}$ & $\begin{array}{l}3990 \\
(1205)\end{array}$ & $\begin{array}{l}3674 \\
(857)\end{array}$ & $\begin{array}{l}21095 \\
(4313)\end{array}$ & $\begin{array}{l}23815 \\
(3876)\end{array}$ & $\begin{array}{l}22455 \\
(2894)\end{array}$ \\
\hline Workforce & $\begin{array}{l}232 \\
(24)\end{array}$ & $\begin{array}{l}356 \\
(63)\end{array}$ & $\begin{array}{l}302 \\
(37)\end{array}$ & $\begin{array}{l}47 \\
(1)\end{array}$ & $\begin{array}{l}44 \\
(1)\end{array}$ & $\begin{array}{l}45 \\
(1)\end{array}$ & $\begin{array}{l}262 \\
(43)\end{array}$ & $\begin{array}{l}289 \\
(45)\end{array}$ & $\begin{array}{l}275 \\
(31)\end{array}$ \\
\hline Workforce50 & $\begin{array}{l}0.737 \\
(0.021)\end{array}$ & $\begin{array}{l}0.684 \\
(0.019)\end{array}$ & $\begin{array}{l}0.707 \\
(0.014)\end{array}$ & $\begin{array}{l}0.390 \\
(0.045)\end{array}$ & $\begin{array}{l}0.250 \\
(0.035)\end{array}$ & $\begin{array}{l}0.311 \\
(0.028)\end{array}$ & $\begin{array}{l}0.798 \\
(0.039)\end{array}$ & $\begin{array}{l}0.826 \\
(0.037)\end{array}$ & $\begin{array}{l}0.812 \\
(0.027)\end{array}$ \\
\hline Works Council & $\begin{array}{l}0.719 \\
(0.021)\end{array}$ & $\begin{array}{l}0.675 \\
(0.020)\end{array}$ & $\begin{array}{l}0.694 \\
(0.015)\end{array}$ & $\begin{array}{l}0.432 \\
(0.046)\end{array}$ & $\begin{array}{l}0.243 \\
(0.035)\end{array}$ & $\begin{array}{l}0.326 \\
(0.029)\end{array}$ & $\begin{array}{l}0.780 \\
(0.040)\end{array}$ & $\begin{array}{l}0.789 \\
(0.039)\end{array}$ & $\begin{array}{l}0.784 \\
(0.028)\end{array}$ \\
\hline Union & $\begin{array}{l}0.553 \\
(0.024)\end{array}$ & $\begin{array}{l}0.539 \\
(0.021)\end{array}$ & $\begin{array}{l}0.545 \\
(0.016)\end{array}$ & $\begin{array}{l}0.339 \\
(0.044)\end{array}$ & $\begin{array}{l}0.184 \\
(0.032)\end{array}$ & $\begin{array}{l}0.252 \\
(0.026)\end{array}$ & $\begin{array}{l}0.651 \\
(0.046)\end{array}$ & $\begin{array}{l}0.642 \\
(0.046)\end{array}$ & $\begin{array}{l}0.647 \\
(0.032)\end{array}$ \\
\hline $\begin{array}{l}\text { Employee Decision } \\
\text { Making }\end{array}$ & $\begin{array}{l}0.712 \\
(0.022)\end{array}$ & $\begin{array}{l}0.542 \\
(0.021)\end{array}$ & $\begin{array}{l}0.616 \\
(0.015)\end{array}$ & $\begin{array}{l}0.754 \\
(0.040)\end{array}$ & $\begin{array}{l}0.520 \\
(0.041)\end{array}$ & $\begin{array}{l}0.622 \\
(0.030)\end{array}$ & $\begin{array}{l}0.688 \\
(0.045)\end{array}$ & $\begin{array}{l}0.532 \\
(0.048)\end{array}$ & $\begin{array}{l}0.610 \\
(0.033)\end{array}$ \\
\hline $\begin{array}{l}\text { Information to } \\
\text { Employees }\end{array}$ & $\begin{array}{l}0.527 \\
(0.024)\end{array}$ & $\begin{array}{l}0.600 \\
(0.021)\end{array}$ & $\begin{array}{l}0.568 \\
(0.016)\end{array}$ & $\begin{array}{l}0.466 \\
(0.046)\end{array}$ & $\begin{array}{l}0.493 \\
(0.041)\end{array}$ & $\begin{array}{l}0.481 \\
(0.030)\end{array}$ & $\begin{array}{l}0.569 \\
(0.048)\end{array}$ & $\begin{array}{l}0.651 \\
(0.046)\end{array}$ & $\begin{array}{l}0.610 \\
(0.033)\end{array}$ \\
\hline Observations & 438 & 570 & 1008 & 118 & 152 & 270 & 109 & 109 & 218 \\
\hline
\end{tabular}

Standard errors in parentheses.

remainder-union and time-are clearly defined. Our interest is in the estimated coefficient $\alpha_{1}$ which represents the works council impact on total factor productivity.

In addition to this basic specification, we estimate an equation which contains terms that allow for interactive effects between works councils and unions, voice, and information sharing variables-wc* union, $w c *$ voice and $w c *$ info. If the works council impact on productivity is bolstered by the presence of a union, the coefficient on the interaction term $w c *$ union will be positive. A strong indication that informal voice and information sharing arrangements are substitutes for works councils in generating productivity impacts is signaled by estimated coefficients on the stand-alone voice and information sharing variables - voice and info-that are positive and of greater combined quantitative magnitude than the works council effect - the sum of the coefficient on the stand alone works council variable, $w c$, and the coefficients on the interaction terms $w c *$ voice and $w c *$ info, with the latter two properly weighted by the density of voice and information sharing arrangements in works council settings, respectively. Negative estimated coefficients on the interaction terms are a weaker indication of substitutability.

We begin with a simple OLS estimation procedure with random effects to account for the fact that a subset of the sample is repeated observations on the same 
establishments. A concern with this specification procedure is that unobserved firm heterogeneity may prevent us from identifying the true causal impact of works councils on productivity. We begin to address concerns of this sort by estimating a fixed effects model which utilizes the panel aspect of the data to control for timeinvariant unobserved firm features.

Fixed-effects estimation identifies the productivity impact of works councils based on the change in productivity taking place at firms that undergo a change in works council status over the period 1998 to 2004. Time invariant features of firms are thus controlled for in the fixed effects estimates. With this procedure, one must be assured that there exists an adequate number of changers, that measurement error in the works council variable is not exacerbated by virtue of the focus on changers, and that changers are a random draw from the larger set of establishments. Each is a challenge in our analysis.

Regarding the number of changers, only 11 of the 109 panel of establishments changed works council status over the period (6 acquiring and 5 abandoning), 11 changed union status ( 5 acquiring and 6 abandoning), 43 changed employee decision making status (13 acquiring and 30 abandoning), and 49 changed information sharing status (26 acquiring and 23 abandoning). Because we are also interested in the interaction terms in this analysis, it is important to note that works councils changed status quite independently of the other variables - of the 11 firms changing works council status, 9, 5, and 7 did so without changing union, employee decision making, and information sharing status, respectively. These are uncomfortably small numbers on which to estimate the works council impact on productivity, but as part of a larger set of findings the results are illustrative.

The error with which a variable is measured may be exacerbated when the focus is on changers, and especially so when (as is true in this case) the variable of interest changes very little over time. Measurement error leads to estimated effects that are biased towards zero. ${ }^{8}$ Non-random selection into and out of works council status over this period is also a potential problem for the fixed effects analysis. For example, it seems reasonable to expect that establishments adopting works councils are likely to be those that benefit the most from their presence, while those abandoning works councils receive the least benefit (or even a loss) due to their presence.

Because of these concerns with the fixed effects specification, we invoke an alternative identification strategy — a regression discontinuity design — which utilizes a different procedure to address bias due to unobserved heterogeneity. The basic thrust behind the regression discontinuity approach is to identify an exogenous "sorting" mechanism - in our case, something that exogenously sorts firms into and out of works council status - and then to compare the outcome variable of interestin our case, total factor productivity - across the observations that are just on the cusp of being sorted into and out of the category of interest.

The premise, which can be subjected to limited empirical investigation, is that observations just on the cusp of the sorting mechanism cutoff criterion are likely to be very similar with respect to both observed and unobserved characteristics. Moreover,

\footnotetext{
${ }^{8}$ Six of the eleven establishments witnessing a change in works council status over the period also crossed the 50-worker threshold in doing so-an indication that, for these firms at least, the recorded change in status is not due to measurement error.
} 
because the sorting mechanism is exogenous, the assignment of a works council to these establishments is likely to be a purely random event, thereby tackling the problem of unobserved heterogeneity due to self selection. In a valid regression discontinuity design, any difference in the outcome variable across the "treated" and "control" groups is truly causally related to the "treatment." In our case, possessing a works council is the treatment, the sorting mechanism that places firms into the "treated" and "control" groups is the French legal mandate that firms with 50 or more workers must possess a works council, and the outcome is productivity.

The basic econometric framework for regression discontinuity involves replacing the variable of causal interest in the outcome regression with (1) a dichotomous variable indicating whether the cutoff point for sorting into the "treated" status has been reached and (2) a (typically nonlinear) functional relationship composed of the values on the sorting criterion itself, which allows the estimated coefficient on the dichotomous cutoff variable to capture the difference in the dependent variable for observations in a narrow band around the cutoff criterion. The coefficient on the dichotomous cutoff variable is taken to be an estimate of the true causal impact. ${ }^{9}$

This approach is valid if the sorting criterion is sharp-that is, if those establishments in our sample that meet or exceed the cutoff criterion are assigned works councils and those below the cutoff are not. However, in our case the "50 or greater" cutoff criterion is not decisive (see Table 3): there are firms in our data with fewer than 50 workers that nonetheless possess works councils (32 of 295) and firms with 50 or more workers that do not possess works councils (45 of 713). Thus, there is endogenous, voluntary adoption below the sorting criterion and noncompliance at or above it. Under these circumstances, a "fuzzy" regression discontinuity technique is appropriate. This approach mimics the basic regression discontinuity design, but takes into account the "fuzziness" of the sorting criterion by using the dichotomous cutoff variable as an "identifying" variable in a first-stage regression equation that models works council status, thereby allowing for the creation of an instrumental variable for works council status that is used in the total factor productivity regressions (Imbens and Angrist 1994). It is the coefficient on the instrumented works council variable that is the estimate of the true causal impact of works councils on productivity in this design.

The empirical methodology is as follows:

$$
\begin{aligned}
& w c_{\text {it }}=\theta_{0}+\theta_{1}{\text { workforce } 50_{i t}}+\theta_{2} w\left(\text { workforce }_{\text {it }}\right)+\theta_{3} \text { union }_{\text {it }}+\theta_{4} \text { voice }_{\text {it }} \\
& +\theta_{5} \text { info }_{\text {it }}+\theta_{6} \text { time }+\theta_{7} I_{\text {it }}+\varsigma_{\text {it }}
\end{aligned}
$$

is the first-stage, instrumenting equation which is used to derive the instrumental variable $w c^{*}$ which is then used in a total factor productivity regression of the following form:

$$
\begin{aligned}
\text { TFP }_{\text {it }}= & \beta_{0}+\beta_{1} \text { wc }^{*}{ }_{\text {it }}+\beta_{2} w\left(\text { workforce }_{\text {it }}\right)+\beta_{3} \text { union }_{\text {it }}+\beta_{4} \text { voice }_{\text {it }}+\beta_{5} \text { info }_{\text {it }} \\
& +\beta_{6} \text { time }+\beta_{7} I_{\mathrm{it}}+v_{\mathrm{it}}
\end{aligned}
$$

\footnotetext{
${ }^{9}$ See Imbens and Lemieux (2008) for a review of econometrics issues surrounding the regression discontinuity design.
} 
Table 3 Distribution of workforce by works council status

\begin{tabular}{lrrr}
\hline Worforce & \multicolumn{2}{c}{ Works council } & Total \\
\cline { 2 - 3 } & No & Yes & \\
\hline$<49$ & 263 & 32 & 295 \\
$\geq 50-100$ & 26 & 151 & 177 \\
$100-200$ & 11 & 204 & 215 \\
$200-300$ & 2 & 105 & 107 \\
$300-400$ & 2 & 29 & 31 \\
$400-500$ & 1 & 44 & 45 \\
$500-600$ & 0 & 28 & 28 \\
$600-700$ & 0 & 22 & 22 \\
$700-800$ & 0 & 15 & 15 \\
$800-900$ & 0 & 14 & 14 \\
$900-1,000$ & 0 & 11 & 11 \\
$\geq 1,000$ & 3 & 45 & 48 \\
Total & 308 & 700 & 1008 \\
\hline
\end{tabular}

Workforce 50 is the dichotomous cutoff variable, and w(workforce) is a linear combination of the workforce variable in linear, quadratic and cubic form. This nonlinear relationship of the sorting criterion forces a comparison of productivity for the "treated" (i.e., establishments with works councils) and "control" (i.e., establishments without works councils) groups within a narrow band around the cutoff itself. The coefficient $\beta_{1}$ represents an estimate of the true causal impact of works councils on total factor productivity. ${ }^{10}$

As a check on the full regression results, it is common in the literature to estimate Eqs. 2 and 3 using a smaller sample, one that represents a narrow band around the cutoff criterion. We do this for the sample of establishments with workforce size between 30 and 70, inclusive. (See Table 2 for descriptive statistics on this sample.) We may also utilize this sample to test for similarity in the values of establishment covariates across the "treated" and "control" populations. A comparison of means on the various control variables across the 30-49 and 50-70 samples reveals no statistically significant differences with the exception of union status, which is significantly larger for the sample of firms with workforce size between 50 and 70 , inclusive.

A clear advantage of the regression discontinuity design over the fixed effects specification is that the estimated works council impact on productivity from the former estimation procedure is based on a larger number of observations-1008 versus 218. (Twenty of these observations come from 10 of the 11 firms that changed works council status over the two periods.) Even the smaller sample, with

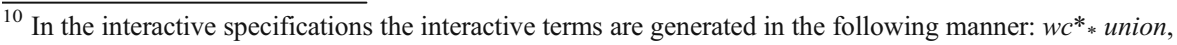
$w c^{*} *$ voice and $w c^{*} *$ info.
} 
firms in the 30-70 workforce range, contains 270 observations. While the regression discontinuity design is superior in this respect, it is not without possible flaws.

For example, although noncompliance with the mandate appears to be an option for establishments above the cutoff criterion, some firms may be uncomfortable with this form of works council avoidance. One possible alternative route is to strategically keep employment below 50 in order to avoid triggering the onset of a works council. As a way of testing for this form of manipulation (and possible bias in the regression discontinuity results), McCrary (2008) suggests exploring the number of establishments in equally-sized bins around the cutoff criterion to see if there is inordinate clustering-in this case, below the threshold. There are 28 firms in the 46-48 range and 22 firms in the 52-54 range. Widening the ranges a bit, there are 76 firms in the 40-48 range and 43 firms in the 52-60 range. Although perhaps not alarmingly different, the distribution of firms is clearly not uniform in a range around the 50 worker threshold. This is something to bear in mind as we turn to the results.

\section{Results}

Table 4 gives the results of the total factor productivity regressions invoking random and fixed effects. Column (1) gives the log-in-log production function estimation results, the residuals from which form the values of the dependent variable in the total factor productivity regression results in the remaining columns. ${ }^{11}$ Turning, first, to the random effects results in column (2), we see that, although positive, the works council impact on productivity is quantitatively very small and not statistically significant. In fact, except for the linear time trend-indicating a roughly $12 \%$ increase in total factor productivity over the period 1998-2004 - the only variables of any significance statistically are the voice and information sharing variables. Granting employees a decision making voice in production and sharing pertinent information with them yield an $8 \%$ and $6 \%$ bump in productivity, respectively.

Is there any indication that unions promote superior works council impacts on productivity, or that voice and information sharing arrangements lead to significant productivity impacts in non-works council settings? For evidence on these, we turn to the interactive results in column (3). The first thing to note about these findings is that the data are not entirely up to the task of separating out the various sought after effects; none of either the stand alone or interactive variables is statistically significantly different from zero. Ignoring the imprecision of the estimated impacts, however, we are forced to conclude that there is virtually no support for the view that productivity outcomes are superior for works councils when they are

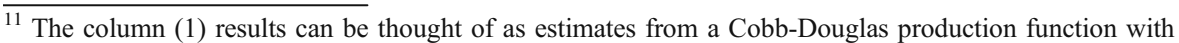
the coefficients on the labor and capital variables representing the labor and capital share in value added, respectively. Dating back to the seminal work of Douglas and his co-authors (e.g., Bronfenbrenner and Douglas 1939), the estimated value of labor's share in total output has historically been in the range of 0.75 . Our estimates in this paper range from 0.8 to 0.9 , but these are derived from a value added (as opposed to output) equation and for single-establishment firms (as opposed to all firms), and as a result might be expected to be even higher than average. Our results are thus consistent with the literature.
} 
Table 4 Total factor productivity regressions with random and fixed effects

\begin{tabular}{|c|c|c|c|c|c|}
\hline & (1) & (2) & (3) & (4) & (5) \\
\hline Independent variable & log_VA & Random effects & Random effects & Fixed effects & Fixed effects \\
\hline log_Workforce & $\begin{array}{l}0.901 * \\
(0.019)\end{array}$ & & & & \\
\hline log_Capital & $\begin{array}{l}0.142 * \\
(0.011)\end{array}$ & & & & \\
\hline Works Council & & $\begin{array}{l}0.002 \\
(0.041)\end{array}$ & $\begin{array}{l}0.008 \\
(0.065)\end{array}$ & $\begin{array}{l}-0.034 \\
(0.103)\end{array}$ & $\begin{array}{l}-0.023 \\
(0.121)\end{array}$ \\
\hline Union & & $\begin{array}{l}-0.05 \\
(0.039)\end{array}$ & $\begin{array}{l}0.058 \\
(0.088)\end{array}$ & $\begin{array}{l}-0.095 \\
(0.097)\end{array}$ & $\begin{array}{l}-0.022 \\
(0.198)\end{array}$ \\
\hline Employee Decision Making & & $\begin{array}{l}0.081^{*} \\
(0.031)\end{array}$ & $\begin{array}{l}0.072 \\
(0.054)\end{array}$ & $\begin{array}{l}-0.027 \\
(0.052)\end{array}$ & $\begin{array}{l}-0.044 \\
(0.103)\end{array}$ \\
\hline Information to Employees & & $\begin{array}{l}0.061 * * \\
(0.030)\end{array}$ & $\begin{array}{l}0.042 \\
(0.054)\end{array}$ & $\begin{array}{l}0.07 \\
(0.050)\end{array}$ & $\begin{array}{l}0.113 \\
(0.123)\end{array}$ \\
\hline Works Council*Union & & & $\begin{array}{l}-0.134 \\
(0.097)\end{array}$ & & $\begin{array}{l}-0.111 \\
(0.229)\end{array}$ \\
\hline Works Council*Employee & & & $\begin{array}{l}0.016 \\
(0.065)\end{array}$ & & $\begin{array}{l}0.014 \\
(0.122)\end{array}$ \\
\hline Works Council*Information & & & $\begin{array}{l}0.025 \\
(0.065)\end{array}$ & & $\begin{array}{l}-0.059 \\
(0.136)\end{array}$ \\
\hline Time & & $\begin{array}{l}0.117 * \\
(0.026)\end{array}$ & $\begin{array}{l}0.118 * \\
(0.026)\end{array}$ & $\begin{array}{l}0.083^{* *} \\
(0.032)\end{array}$ & $\begin{array}{l}0.088^{*} \\
(0.033)\end{array}$ \\
\hline Industry Controls & & $\sqrt{ }$ & $\sqrt{ }$ & $\sqrt{ }$ & $\sqrt{ }$ \\
\hline Constant & $\begin{array}{l}10.042 * \\
(0.079)\end{array}$ & $\begin{array}{l}-0.216^{* *} \\
(0.087)\end{array}$ & $\begin{array}{l}-0.210 * * \\
(0.094)\end{array}$ & $\begin{array}{l}0.098 \\
(0.126)\end{array}$ & $\begin{array}{l}0.123 \\
(0.138)\end{array}$ \\
\hline Observations & 1008 & 1008 & 1008 & 218 & 218 \\
\hline
\end{tabular}

Standard errors in parentheses. + significant at $10 \% ; * *$ significant at $5 \%$; ${ }^{*}$ significant at $1 \%$

accompanied by a union presence in the firm - the $w c *$ union interactive variable is negative in magnitude.

The results also suggest that, while firms without works councils represent only about one-third of the sample, the impact of worker voice and information sharing arrangements is quantitatively sizeable in these establishments. Granting to employees decision making responsibility and sharing certain information with them leads to a $7 \%$ and $4 \%$ impact on productivity, respectively, in establishments without works councils. This compares with a $2 \%$ and $3 \%$ impact in works council settings, respectively. If we add to this the rather meager $1 \%$ impact on productivity of other features associated with works councils (as indicated by the estimated coefficient on the stand alone works council variable), the results offer suggestive evidence that worker-friendly human resource practices existing outside of formal works council settings may be suitable substitutes for the activities of works councils 
when it comes to mechanisms for fostering productivity improvement. In fact, it is perhaps for this reason that the incidence of such features in non-works council settings $-59 \%$ of these firms encourage employee decision making and $45 \%$ share information with workers - is almost as large as among firms with works councils (at $63 \%$ and $62 \%$, respectively).

Columns (4) and (5) reproduce the above specifications but employ a fixed effects estimation procedure. This reduces the meaningful sample to 218, or 109 firms and only 11 of which undergo a change in works council status. Sadly, but also perhaps not so surprisingly given the relatively small number of changers in the data, the results do not shed much additional light on the impact of works councils on productivity, or the related hypotheses regarding their impact in unionized establishments and their interaction with worker voice and information sharing arrangements. Although they are estimated with great imprecision, both the column (4) and (5) results offer suggestive evidence of a possible negative impact of works councils on productivity. ${ }^{12}$

In the random effects analysis, the impact of works councils is estimated based on variation both across firms and over time, and, given the absence of numerous control variables, there are no doubt significant determinants of total factor productivity which are also correlated with works council status and for which we have failed to account, thus producing possible bias in the estimated works council effect. Fixed effects estimation eliminates some of this concern by focusing attention on the works council impact estimated from within-firm changes in works council status over time, and thus eliminates bias due to left-out time-invariant features of firms.

It is unclear what to expect, a priori, regarding the direction of the bias in the random effects estimation. However, to the extent firms and workers choose their works council status, it is arguably the case that those that adopt works councils are typically forward-thinking with regard to general human resource practices. If these other practices affect productivity positively, then we might expect the bias in the random effects models to be positive-works council status is standing in for the panoply of other, forward thinking human resource practices that have a positive impact on productivity. And, indeed, there is suggestive evidence for this in the fixed effects findings in Table $4 .^{13}$

The regression discontinuity findings appear in Table 5. These results identify the works council impact on productivity focusing on a different, much larger set of firms as compared to the fixed effects specification. Column (1) gives the results of the first-stage, instrumenting equation that relates the sorting cutoff criterion variableWorkforce 50 - to works council status. It can be seen from these results that the legal mandate positively and significantly affects the works council status of firms. In addition, unions are more likely to exist in firms with works councils, as is information sharing with employees.

\footnotetext{
12 Interestingly, despite much better measures of the capital input than found in the German literature, the basic results in Table 4 are not significantly altered if the capital variable is omitted from the analysis. Perhaps this is the case because our analysis is limited to single-establishment firms, wherein capital intensity is typically both low and less variable.

${ }^{13}$ Random effects estimation using the smaller, 218-observation panel data yield results that are very similar to those in columns (2) and (3) of Table 4, except that the "employee decision making" variable becomes statistically insignificant in the column (2) specification.
} 
Table 5 Regression discontinuity results

(1)

(2)

(3)

Random effects

All establishments

\begin{tabular}{|c|c|c|c|}
\hline \multirow{2}{*}{ Independent variable } & \\
\hline & Works council & TFP & TFP \\
\hline Works Council & & $\begin{array}{l}-0.115^{* *} \\
(0.058)\end{array}$ & $\begin{array}{l}-0.149 * * \\
(0.070)\end{array}$ \\
\hline Workforce 50 & $\begin{array}{l}0.709^{*} \\
(0.021)\end{array}$ & & \\
\hline Workforce & $\begin{array}{l}-1.4 \mathrm{E}-05 \\
(3.1 \mathrm{E}-05)\end{array}$ & $\begin{array}{l}1.1 \mathrm{E}-04+ \\
(6.3 \mathrm{E}-05)\end{array}$ & $\begin{array}{l}1.1 \mathrm{E}-04+ \\
(6.3 \mathrm{E}-05)\end{array}$ \\
\hline Workforce $^{2}$ & $\begin{array}{l}2.55 \mathrm{E}-09 \\
(4.9 \mathrm{E}-09)\end{array}$ & $\begin{array}{l}-2.4 \mathrm{E}-08^{* *} \\
(9.9 \mathrm{E}-09)\end{array}$ & $\begin{array}{l}-2.45 \mathrm{E}-08^{* *} \\
(9.9 \mathrm{E}-09)\end{array}$ \\
\hline Workforce $^{3}$ & $\begin{array}{l}-9.17 \mathrm{E}-14 \\
(1.3 \mathrm{E}-13)\end{array}$ & $\begin{array}{l}6.3 \mathrm{E}-13 * * \\
(2.6 \mathrm{E}-13)\end{array}$ & $\begin{array}{l}6.49 \mathrm{E}-13 * \\
(2.6 \mathrm{E}-13)\end{array}$ \\
\hline Union & $\begin{array}{l}0.209^{*} \\
(0.019)\end{array}$ & $\begin{array}{l}-0.01 \\
(0.044)\end{array}$ & $\begin{array}{l}0.064 \\
(0.087)\end{array}$ \\
\hline Employee Decision Making & $\begin{array}{l}-0.006 \\
(0.017)\end{array}$ & $\begin{array}{l}0.083 * \\
(0.031)\end{array}$ & $\begin{array}{l}0.053 \\
(0.050)\end{array}$ \\
\hline Information to Employees & $\begin{array}{l}0.039 * * \\
(0.016)\end{array}$ & $\begin{array}{l}0.072 * * \\
(0.030)\end{array}$ & $\begin{array}{l}0.03 \\
(0.053)\end{array}$ \\
\hline Works Council*Union & & & $\begin{array}{l}-0.094 \\
(0.096)\end{array}$ \\
\hline Works Council*Employee & & & $\begin{array}{l}0.047 \\
(0.057)\end{array}$ \\
\hline Works Council*Information & & & $\begin{array}{l}0.059 \\
(0.062)\end{array}$ \\
\hline Time & $\begin{array}{l}-0.005 \\
(0.016)\end{array}$ & $\begin{array}{l}0.114^{*} \\
(0.026)\end{array}$ & $\begin{array}{l}0.114^{*} \\
(0.026)\end{array}$ \\
\hline Industry Controls & $\sqrt{ }$ & $\sqrt{ }$ & $\sqrt{ }$ \\
\hline Constant & $\begin{array}{l}0.064 \\
(0.042)\end{array}$ & $\begin{array}{l}-0.182^{* *} \\
(0.088)\end{array}$ & $\begin{array}{l}-0.149 \\
(0.092)\end{array}$ \\
\hline Observations & 1008 & 1008 & 1008 \\
\hline
\end{tabular}

Standard errors in parentheses. + significant at $10 \% ; * *$ significant at $5 \%$; $*$ significant at $1 \%$

The total factor productivity regression results, with the instrumented works council variable, appear in columns (2) and (3). The most striking result from these estimated equations is that works councils are found to be statistically significantly and negatively related to firm productivity. This finding is hinted at in the fixed effects results. Looking at the column (2) specification, we see that the estimated 
coefficients on the worker voice and information sharing variables are similar in both magnitude and statistical significance to their effects on productivity in the OLS random effects estimation results of Table 4, column (2): granting employees certain decision making ability and sharing particular kinds of information with them enhances productivity by $8 \%$ and $7 \%$, respectively. The estimated union effect on productivity, although still statistically insignificant, is unchanged in sign and only slightly changed in magnitude as compared with the OLS random effects results.

Unfortunately, once again the interactive specification results are not very revealing. However, one might safely conclude from these findings that there is little evidence of a positive boost to productivity from combining works councils and unions. As with the interactive findings in Table 4, the impact of worker voice and information sharing in non-works council settings are of a sizeable magnitude, roughly half the quantitative impact in the non-interactive specification of column (2) and virtually the equivalent of or greater than the impact observed when these same human resource practices exist in works council settings. Adding to the latter the quite large and statistically significantly negative impact of works councils on productivity in settings where these human resource practices are absent, and, once again, there is suggestive evidence that the informal existence of such practices outside of formal works council structures might well provide a viable substitute to works councils when it comes to human resource mechanisms for productivity enhancement.

Finally, as a check on these results Table 6 gives the regression discontinuity findings for the smaller, 30-70 workforce sample which narrowly straddles the 50 -worker cutoff criterion. The results are estimated with less precision than in the larger sample, and the quantitative magnitudes of the estimated impacts seem less plausibly accurate, but the general conclusion stands - namely, that the works councils are found to have a negative and statistically significant impact on firm productivity. Interestingly, we find no evidence that voice or information-sharing features affect firm productivity in the column (3) specification for this sample of establishments. However, there is some slightly suggestive evidence in the column (4) results that these characteristics interact with works council status in significant ways - negatively, in the case of worker voice, and positively, in the case of information sharing.

\section{Conclusion}

This paper presents the first empirical evidence of which we are aware on the impact of works councils on firm productivity in France. The data are restricted to observations on single establishment firms, and so the findings may well change once data become available on the multi-establishment firm sector. That said, our results offer no evidence that French works councils have a positive impact on firm productivity. Indeed, in the regression discontinuity findings we see some evidence that works councils have a negative impact on productivity. Moreover, our results offer no support for a claim that the works council impact on productivity is superior in unionized environments. 
Table 6 Regression discontinuity results for workforce 30-70 sample

\begin{tabular}{|c|c|c|c|c|}
\hline \multirow[b]{4}{*}{ Independent variable } & & (2) & (3) & (4) \\
\hline & \multicolumn{4}{|c|}{ Random effects } \\
\hline & \multicolumn{4}{|c|}{ Establishments with workforce $30-70$} \\
\hline & $\log \mathrm{VA}$ & Works council & TFF & TFP \\
\hline log_Workforce & $\begin{array}{l}0.811^{*} \\
(0.106)\end{array}$ & & & \\
\hline log_Capital & $\begin{array}{l}0.149 * \\
(0.022)\end{array}$ & & & \\
\hline Works Council & & & $\begin{array}{l}-0.569+ \\
(0.339)\end{array}$ & $\begin{array}{l}-0.727^{* *} \\
(0.337)\end{array}$ \\
\hline Workforce 50 & & $\begin{array}{l}0.283 * \\
(0.097)\end{array}$ & & \\
\hline Workforce & & $\begin{array}{l}-0.323^{* *} \\
(1.5 \mathrm{E}-01)\end{array}$ & $\begin{array}{l}-0.344 \\
(2.4 \mathrm{E}-0)\end{array}$ & $\begin{array}{l}-0.399+ \\
(2.3 \mathrm{E}-01)\end{array}$ \\
\hline Workforce $^{2}$ & & $\begin{array}{l}0.007 * * \\
(3.0 \mathrm{E}-03)\end{array}$ & $\begin{array}{l}0.008 \\
(5.0 \mathrm{E}-03)\end{array}$ & $\begin{array}{l}0.009+ \\
(5.0 \mathrm{E}-03)\end{array}$ \\
\hline Workforce $^{3}$ & & $\begin{array}{l}-4.80 \mathrm{E}-05^{*} \\
(3.2 \mathrm{E}-03)\end{array}$ & $\begin{array}{l}-5.3 \mathrm{E}-05 \\
(3.4 \mathrm{E}-05)\end{array}$ & $\begin{array}{l}-6.0 \mathrm{E}-05+ \\
(3.4 \mathrm{E}-05)\end{array}$ \\
\hline Union & & $\begin{array}{l}0.263 * \\
(0.051)\end{array}$ & $\begin{array}{l}0.145 \\
(0.100)\end{array}$ & $\begin{array}{l}0.248 * * \\
(0.113)\end{array}$ \\
\hline Employee Decision Making & & $\begin{array}{l}-0.024 \\
(0.046)\end{array}$ & $\begin{array}{l}-0.026 \\
(0.045)\end{array}$ & $\begin{array}{l}0.009 \\
(0.048)\end{array}$ \\
\hline Information to Employees & & $\begin{array}{l}0.031 \\
(0.041)\end{array}$ & $\begin{array}{l}0.059 \\
(0.040)\end{array}$ & $\begin{array}{l}-0.021 \\
(0.048)\end{array}$ \\
\hline Works Council*Union & & & & $\begin{array}{l}-0.08 \\
(0.099)\end{array}$ \\
\hline Works Council*Employee & & & & $\begin{array}{l}-0.128+ \\
(0.068)\end{array}$ \\
\hline Works Council*Information & & & & $\begin{array}{l}0.208^{*} \\
(0.075)\end{array}$ \\
\hline Time & & $\begin{array}{l}-0.062 \\
(0.041)\end{array}$ & $\begin{array}{l}0.039 \\
(0.041)\end{array}$ & $\begin{array}{l}0.028 \\
(0.040)\end{array}$ \\
\hline Industry Controls & & $\sqrt{ }$ & $\sqrt{ }$ & $\sqrt{ }$ \\
\hline Constant & $\begin{array}{l}10.305^{*} \\
(0.389)\end{array}$ & $\begin{array}{l}5.076^{* *} \\
(2.253)\end{array}$ & $\begin{array}{l}5.05 \\
(3.581)\end{array}$ & $\begin{array}{l}5.955+ \\
(3.520)\end{array}$ \\
\hline Observations & 270 & 270 & 270 & 270 \\
\hline
\end{tabular}

Standard errors in parentheses. + significant at $10 \% ; * *$ significant at $5 \%$; ${ }^{*}$ significant at $1 \%$ 
Perhaps the most interesting findings from our analysis are that worker voice and information sharing human resource practices are widely utilized in French firms, that this is true independent of works council status, and that these features are positive, statistically significant and quantitatively important determinants of firm productivity. Thus, one possible explanation for the lack of a positive impact of works councils on firm productivity is that many of the features of works councils that may serve to foster enhanced productivity are informally in existence and relatively pervasive across French firms, independent of works council status.

Acknowledgment We received helpful comments on earlier versions of this manuscript from Thomas Breda, Mindy Marks, Todd Sorensen, two anonymous referees, and participants in a session at the 2009 Eastern Economic Association Meetings in New York. In addition, we have benefited from the able research assistance of Trinidad Beleche and Daniel Farhat. The data for this study are used in accordance with a convention set by the French Ministry of Labor.

Open Access This article is distributed under the terms of the Creative Commons Attribution Noncommercial License which permits any noncommercial use, distribution, and reproduction in any medium, provided the original author(s) and source are credited.

\section{References}

Addison JT (2010) The Economics of Codetermination: lessons from the German experience. Palgrave Macmillan, New York

Addison JT, Schank T, Schnabel C, Wagner J (2006) Works councils in the production process. Schmollers Jahrbuch 126(2):251-283

Addison JT, Schnabel C, Wagner J (1997) On the determinants of mandatory works councils in Germany. Ind Relat 36:419-445

Addison JT, Schnabel C, Wagner J (2001) Works councils in Germany: their effects on establishment performance. Br J Ind Relat 42:255-281

Askenazy P, Thesmar D, Thoenig M (2006) Time based competition and innovation. Econ J 116 (508):128-154

Bronfenbrenner M, Douglas PH (1939) Cross-section studies in the Cobb-Douglas function. J Polit Econ 47(6):761-785

Caroli E, Van Reenen J (2001) Skill-biased organizational change? Evidence from a panel of British and French establishments. Q J Econ 116(4):1449-1492

Douglas P (1921) Shop committees: substitutes for, or supplement to, trades-unions? J Polit Econ 29:89107

Fairris D (2002) Are transformed workplaces more productively efficient? J Econ Issues 36(3):659-670

Freeman RB, Lazear EP (1995) An economic analysis of works councils. In: Rodgers JR, Streeck W (eds) Works Councils: consultation, representation, and co-operation in industrial relations. University of Chicago Press, Chicago

Gerlach K, Jirjahn U (2001) Employer provided further training: Evidence from German establishment data. Schmollers Jahrbuch 121(2):139-164

Hubler O, Jirjahn U (2002) Arbeitsproduktivitat, ReorganisationsmaBnahmen und Betriebsrate in Lutz Bellmann and Arnd Kolling, eds. Betrieblicher Wandel und Fachkraftebedarf. Beitrage zur Arbeitsmarkt-und Berufsforschung, 257. Nuremberg: Institute for Employment Research, pp. 1-45

Hubler O, Jirjahn U (2003) Works councils and collective bargaining in Germany: the impact on productivity and wages. Scott J Polit Econ 50(2):471-491

Imbens G, Angrist J (1994) Identification and estimation of local average treatment effects. Econometrica 62(2):467-476

Imbens G, Lemieux T (2008) Regression discontinuity designs: a guide to practice. J Econom 142(2):615-635

Jenkins A (2000) Employment relations in France: evolution and innovation. Kluwer, New York

Kleiner MM, Lee YM (1997) Works councils and unionization: lessons from South Korea. Ind Relat 36 (1): $1-16$ 
McCrary J (2008) Manipulation of the running variable in a regression discontinuity design: a density test. J Econom 142(2):698-714

OECD (2001) OECD Manual on measuring capital: measurement of capital stocks, consumption of fixed capital and capital services. OECD, Paris

Wagner J (2008) German works councils and productivity: first evidence from a nonparametric test. Appl Econ Lett 15(9):727-730

Zwick T (2004) Employee participation and productivity. Labour Econ 11:715-740 